\title{
Editorial notes for the international journal of LCA
}

\section{Journal Article}

Author(s):

Hungerbühler, Konrad

Publication date:

1999

Permanent link:

https://doi.org/10.3929/ethz-b-000423070

Rights / license:

In Copyright - Non-Commercial Use Permitted

Originally published in:

The International Journal of Life Cycle Assessment 4(1), https://doi.org/10.1007/BF02979385 


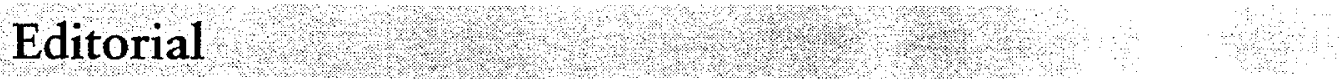

\section{Editorial Notes for the International Journal of LCA}

\author{
Konrad Hungerbühler
}

Corresponding address: Prof. Dr. K. Hungerbühler, ETH Eidgenössische Technische Hochschule Zürich, Laboratorium für Technische Chemie, Gruppe für Sicherheit und Umweltschutz, Universitätsstr. 31, UNK C3; CH-8092 Zurich, Switzerland

For a sustainable use of natural resources, innovative industry and business will have to play a more and more important role. Along with a high value creation, we must find products and services that also promise environmentally sound and safe ways of production, usage, and disposal [1].

In this innovation process, LCA may play a key role. LCA can enlarge the contemporary economically dominated view, which is one-sided, with a holistic environmental understanding. However, this certainly requires that LCA is able to compete in a fast-paced, rapidly changing business world:

Markets and chains of value creation are becoming more dynamic, global, and complex. At the same time, competition is ever increasing. Innovation, cost, information, and time management are increasingly emerging as key factors for success. Customer benefit has become a central issue. This means that life-cycle thinking and aspects of safety and environmental protection concerning the customer have to become more important as well. Safety and environmental technologies are no longer of retrospective concern but a central part of product design.

In order to ensure that LCA attains in such a framework a better standing and effectiveness, its practicability in early development phases of new products and services has to be enhanced. Here we have to overcome a common dilemma within each development process: The degrees of freedom and (at least potential) variety of options are by far greatest in the beginning of a development process. At the same time, knowledge here is still scarce. Data and modelling ideas are rare, relatively undefined, and uncertain. Later on we know more concerning these aspects, yet the costs of error-corrections are much higher. What we have to look for is a systematic approach that iteratively models, assesses, and optimises the entire life cycle with regards to the most important chances and risks. Important aims are an effective and goaloriented generation of high-quality new design versions and the elimination of weaker options.

What implications does this have for the future development of LCA?

Besides more comprehensive and more reliable basic data for the faster build-up of process networks and better con- cepts for a realistic assessment of chemicals, we will primarily need a better understanding of the appropriate use of LCA in all stages of product-specific development processes. This could be achieved by a systematic retrospective investigation of several successful and at the same time important product and service innovations. What we need here initially is a fundamental understanding of innovation management and product development. In the next step we need to clarify, on different levels of knowledge and development, the prerequisites and possibilities for the appropriate stepby-step use of LCA [2]. In the interplay of these examples from practice we finally have to develop a general methodology for a new iterative screening LCA [3-5].

An innovation-orienred LCA being, like the investment calculation, an integrated part of each innovation management, would be without doubt an important step in the direction of a more sustainable technology development. Yet, it would not be surprising if the LCA interpretation step so far little noticed by science and therefore underdeveloped, would become a major 'pièce de résistance'.

The EU concerted action CHAINET [6] which aims at linking experts on environmental decision support tools with industrial problem-owners, could be a step in the right direction.

\section{References}

[1] Hungerbühler, K., Ranke, J., Mettier, T.: Chemische Produkte und Prozesse - Grundkonzepte zum umweltorientierten Design. Springer-Verlag, Berlin, 1998

[2] WeNZEL, H.: Application Dependency of LCA Methodology: Key Variables and Their Mode of Influencing the Method. Int. J. LCA 3, 281, 1998

[3] Christinnsen, K., et al.: Simplifying LCA - Just a Cut? Final Report of SETAC - Europe, LCA Screening and Streamlining Working Group, SETAC-Europe, Brussels, 1997

[4] FleisCHER, G., SCHMIDT, W.: Iterative Screening LCA in an EcoDesign Tool. Int. J. LCA 2, 20, 1997

[5] Weidenhaupt, A., Hungerbühler, K.: Integrated Product Design in Chemical Industry. A Plea for Adequate Life-Cycle Screening Indicators. Chimia 51, 217, 1997

[6] Udo de HaEs, H.A., WrISBERG, N.: European Network on Chain Analysis for Environmental Decision Support. Int. J. LCA 3, 79,1998 